\title{
ロ腔内アプローチ法による㚘骨骨折手術における 術中超音波断層検査法の有用性
}

\author{
澤 裕一郎・川野 大・宮本日出・福井克仁 \\ 中山敦史・高木宣雄・宮城島俊雄
}

\section{Usefulness of intraoperative ultrasonic diagnosis in zygomatic fracture surgery with an intraoral approach}

\author{
Yuichiro Sawa $\cdot$ Dai Kawano $\cdot$ Hizuru Miyamoto $\cdot$ Katsuhito Fukui \\ Atsushi NaKayama $\cdot$ Norio Takagi $\cdot$ Toshio Miyagishima
}

\begin{abstract}
Generally, en bloc zygomatic fractures are treated by open reduction with incisions of the infraorbital rim and supraorbital eyebrow regions. However this method is associated with postoperative complications such as facial scars. An intraoral approach requiring only a maxillary vestibular incision, has been reported in several articles. This method is simple and results in adequate bone reduction and fixation. However, the position of bone fragments in the infraorbital rim cannot be observed. We used an intraoral approach, during intraoperative ultrasonic examination to confirm the condition of infraorbital fragments in 17 patients who had simple en bloc fractures of the zygoma bone body. Ultrasonography showed dynamic bone reduction as distinct real-time images and bone fixation was performed exactly. In selected patients the intaroral approach during ultrasonography, is recommended for en bloc zygomatic fractures.
\end{abstract}

Key words: zygomatic fracture (煩骨骨折), intraoral approach method (ロ腔内アプローチ法), ultrasonic diagnosis（超音波断層検查法）

緒

\section{言}

煩骨骨折は眼球障害, 開口障害, 顔貌の変形, 眼窩下神経 麻痺などのさまざまな症状を引き起こし,このような症状 が認められる場合は観血的手術が適応される。一般的な㚘 骨骨折の観血的整復術は眼窩下縁部と眉毛外側部切開より アプローチし煩骨を整復固定する方法である1，2)，いっぽ う㚘冎前頭縫合部の骨片の離開が少ない症例で眼球障害が なく眼窩下壁骨折を整復する必要のない比較的単純な頪骨 en bloc 骨折では口腔内アプローチ法のみで十分な整復固 定術が行えるとされ手術法の簡便化や審美的な問題が解決 されつつある ${ }^{3,4)}$. しかしこの方法では眼窩下縁や眼窩外 側縁部の骨折部位を直視下に確認できないため骨折片の整

藤枝市立総合病院歯科口腔外科

（主任 : 宮城島俊雄部長）

Oral and Maxillofacial Surgery and Dentistry Fujieda

Municipal General Hospital (Chief: Toshio Miyagishima)

受付日 : 平成11年 8 月 17 日
復状態が把握できない欠点があった.そこで今回われわれ は口腔内アプローチ法のみで手術が可能と判断した en bloc な煩骨骨折に対し, 術中超音波断層検査法を併用した煩骨 骨折観血的手術を行い良好な結果が得られたので報告する.

\section{対象および方法}

頪骨骨折において CT および P-A 法, Water's 法 X 線 写真にて en bloc 骨折と診断された症例で，口腔内アプ ローチ法で手術が可能と判断した症例を対象とした．内訳 は17例（男性13例, 女性 4 例）で煩骨骨体骨折のみ13例, 煩 骨骨体骨折および頓骨弓骨折 2 例, 㚘貝上顎骨骨折 2 例で あった（表 1 ). 使用した超音波診断装置はアロカ社製 SSD 2000 で電子リニア型探触子 $(7.5 \mathrm{MHz})$ にて走查した. 方法 は術前に骨折部位に応じて眼窩下縁部（煩骨上顎縫合部）, 眼窝外側縁部（煩骨前頭縫合部）および煩骨弓部（煩骨側 頭縫合部) などに対し超音波断層検査を行い骨片の偏位量 や偏位方向を診断した. 全身麻醉下に上顎犬歯部より第二 
表 1 症例の内訳

\begin{tabular}{|c|c|}
\hline 煩骨骨折 & 13例 \\
\hline 煩骨骨折＋㚘具弓骨折 & 2例 \\
\hline 煩骨上顎骨骨折 & 2例 \\
\hline 合 & 17例 \\
\hline
\end{tabular}

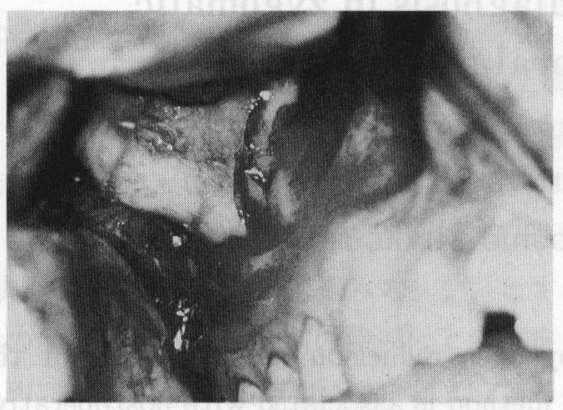

写真 1 右側㚘具骨体骨折症例 上顎洞前壁から㚘骨下稜にかけての骨折 部を示す.

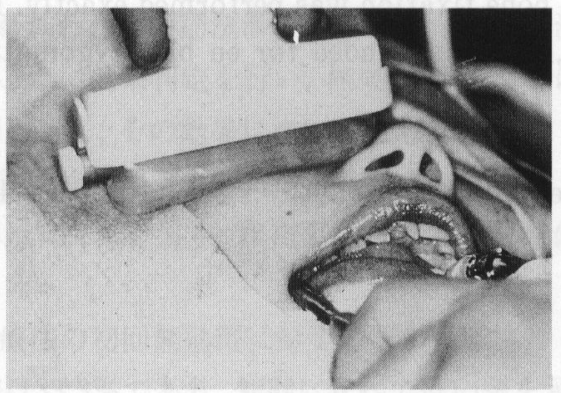

写真 2

眼窝下縁部の超音波検査の実際と㚘骨起 子を用いた口腔内アプローチ法による整 復.

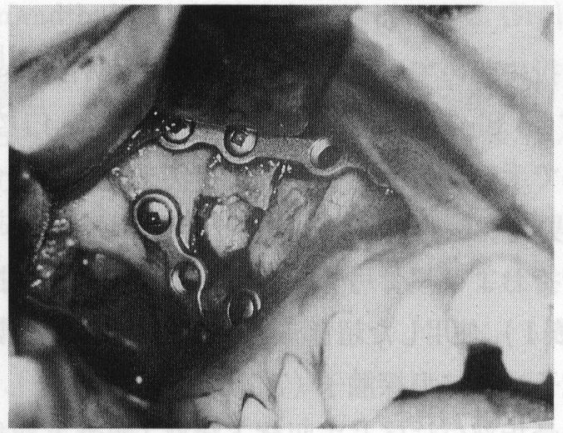

写真 3

チタンマイクロプレートによる固定後

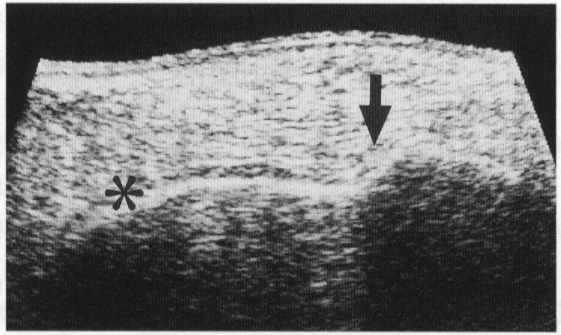

写真 4 術前の超音波検查所見（眼窩 下縁部)

高エコー域の輝線（）は）骨表面を表 し, 輝線が連続性を失い段差を形成し

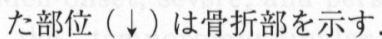

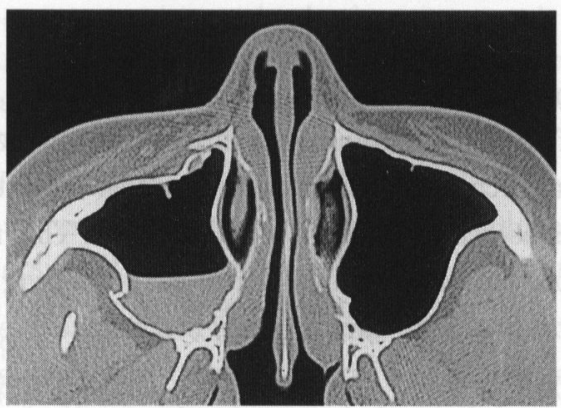

写真 5 術前の CT 所見 右側规骨の内後方転位が認められた.

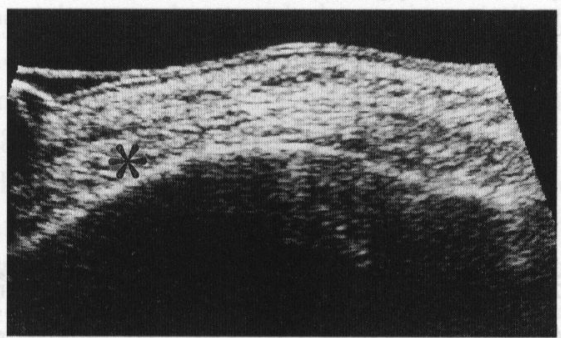

写真 6 術中の超音波検査所見 (眼窩下縁部)

高エコー域の輝線（）は連続性が保たれ た輪郭を形成し整復が行われたことが示 された。

大白歯部付近までの歯肉頬移行部に切開を加え上顎洞前壁 から规骨下稜における骨折部位を明示した (写真 1 ). 術前 に検查した部位（おもに眼窩下縁部）に対し超音波断層検 查を行いながら口腔内より側頭下窩に煩骨起子を挿入し㚘 骨骨体を整復した（写真 2 ).この画像は動画としてモ二 ター上に描出されモニターを見ながら起子を操作し整復し た.モニター上で骨面の段差がほほ消失した位置を整復位 とし上顎洞前壁部および煩骨下稜部などにチタンマイクロ 


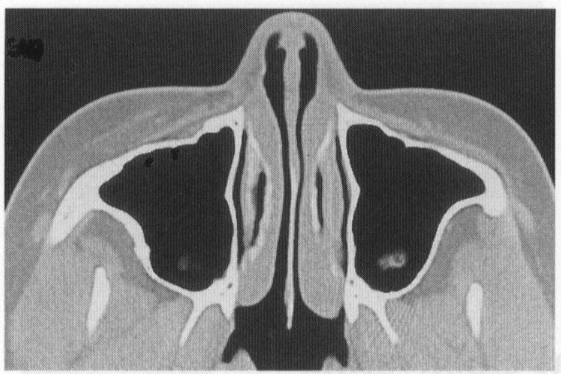

写真 7 術後 6 か月の CT 所見 後戻りも少なく十分な位置へ整復された.

プレートによる固定を行った（写真 3 ). 術後にWater's 法 X 線写真および CT 画像により整復状態を確認した。

\section{結果}

術前超音波断層検查の結果は, 骨表面が高エコー域の輝 線として観察され, 骨折部位は高エコー域の輝線が連続性 を失い段差を形成した画像として認められた（写真 $4 ， 5$ ). 術中の超音波断層検査では断裂した輝線が一致し連続性が 認められ整復が行われたことが示され，術後 6 か月の CT 画像でも骨片の良好な整復が確認され後戻りも少なく満足 な結果であった（写真 6,7 ).

\section{考察}

超音波断層検查法はおもに軟組織の腫瘍や腫瘤の診断に 用いられており，骨に関しての診断は内部構造や骨組織下 の診断が不可能なことからあまり行われていなかった．最 近では単に病変の診断だけでなくエコーガイド下による各 種の処置や術中モニタリングが行われるようになり超音波 断層検查の多彩な可能性が検討されている ${ }^{5,6)}$. 歯科口腔 外科領域でも Akizuki らによる煩骨弓骨折の術中モニタリ ングや Hirai らによる顔面骨骨折の診断に応用され有用で あったと述べられている7，8).いっぼう㚘具骨体の en bloc 骨折における一般的な観血的整復術は眼窩下縁部および眉 毛外側部切開による方法であるが, 眼窩下縁部の切開法は 血腫による眼窩内部への影響や顔面皮膚の瘡痕形成などの 合併症を生じる可能性があるといわれている ${ }^{9)}$ ，そこで口 腔内アプローチ法による観血的整復術が報告され，口腔内 アプローチのみでも十分な骨片の授動および整復が行え， 上顎洞前壁から煩骨下稜部のプレート固定で十分に固定で きるとされている ${ }^{3,4)}$. 実際にわれわれも同方法による手 術を行ったところ煩骨は整復可能で術後の骨片の再転位な どをきたすことはなかった。この方法は簡単で手術時間も 短く合併症も少ないが, 眼窩下縁部の骨折を直視下に置け ないため整復状態の確認ができない問題点がある．そこて
今回はまず頬骨骨折に対し術前に眼窩下縁部, 眼窩外側縁 部および煩骨弓部に超音波断層検査を行い骨片の偏位を確 認した. そして術中も同部に超音波断層検查を行い整復状 態を確認した.この画像はモニターで動画として観察され るため整復状態の確認だけでなく整復時の骨片の動きをり アルタイムに観察することができた.これにより口腔内ア プローチ法の欠点である眼窩下縁部の整復状態の確認が可 能となり効果的な手術が行えるようになった．もし超音波 断層検查の結果で十分な整復が行えないと判断した場合に はじめて眼窩下縁部や眉毛外側部に切開を追加して直視下 に手術を行うことになる. 超音波断層検查は術中 X 線写真 やX線透視法と比較して簡単で何回も行え体位変換も必 要なくX 線被爆がないなどの利点もある. 以上より㚘骨骨 体の en bloc 骨折における口腔内アプローチ法による観血 的整復術時に術中超音波断層検査法を併用することで安全 かつ確実な手術が行えると考えられた。

\section{結語}

術中超音波断層検查法は眼窩下緣部などの整復状態を非 切開で経皮的に観察できることから口腔内アプローチ法に よる㚘冎骨折観血的手術に併用し有用であったので報告し た.

\section{引 用 文 献}

1）田嶋定夫：顔面骨骨折の治療. 第 1 版, 克誠堂出版 株式会社, 東京, 1987, 70-94頁.

2) Keith, D.A.: Atlas of Oral and Maxillofacial Surgery. 1 st Ed, WB Saunders Co, Philadelphia, 1992, p $3-12$.

3）宮島 哲, 星 栄一, 他: 煩骨体部骨折および煩骨 弓骨折の口腔内アプローチによる整復. 形成外科 36: 275-283 1993.

4）上山吉哉, 西山明慶, 他 : 眉毛切開と上䫟口腔前庭 切開を用いた煩骨骨折の治療. 日口外誌 40: 613-615 1994.

5）小野村敏信：整形外科領域における超音波診断の応 用. MB Orthop 11: 1- 4 1998.

6）加藤昭彦, 山田弘之, 他 : 当科における甲状腺超音 波ガイド下吸引細胞診の検討. 日耳鼻 100：45-50 1997.

7) Akizuki, H., Yoshida, H., et al.: Ultrasonographic evaluation during reduction of zygomatic arch fractures. J Cranio Maxillofac Surg 18: 263-266 1990.

8) Hirai, T., Ernest, K.M., et al.: Ultrasonic observation of facial bone fractures. J Oral Maxillofac Surg 54: 776-780 1996.

9) Edward, E., and Winai, K.: Analysis of treatment for isolated zygomaticomaxillary complex fractures. J Oral Maxillofac Surg 54: 3864001996. 